\title{
Are External Cervical Orthoses Necessary after Anterior Cervical Discectomy and Fusion: A Review of the Literature
}

\author{
Richard Camara $^{1}$, Olaide O. Ajayi ${ }^{1}$, Farbod Asgarzadie ${ }^{2}$ \\ 1. Department of Neurosurgery, Loma Linda University Medical Center 2. Fontana Medical Center, Kaiser \\ Permanente Southern California
}

$\square$ Corresponding author: Richard Camara, camaratwinrc@aol.com

Disclosures can be found in Additional Information at the end of the article

\section{Abstract}

Introduction \& Background: The use of external cervical orthosis (ECO) after anterior cervical discectomy and fusion (ACDF) varies from physician to physician due to an absence of clear guidelines. Our purpose is to evaluate and present evidence answering the question, "Does ECO after ACDF improve fusion rates?” through a literature review of current evidence for and against ECO after ACDF.

Review: A PubMed database search was conducted using specific ECO and ACDF related keywords. Our search yielded a total of 1,267 abstracts and seven relevant articles. In summary, one study provided low quality of evidence results supporting the conclusion that external bracing is not associated with improved fusion rates after ACDF. The remaining six studies provide very low quality of evidence results; two studies concluded that external bracing after cervical procedures is not associated with improved fusion rates, one study concluded that external bracing after cervical procedures is associated with improved fusion rates, and the remaining three studies lacked sufficient evidence to draw an association between external bracing after ACDF and improved fusion rates.

Conclusion: We recommend against the routine use of ECO after ACDF due to a lack of improved fusion rates associated with external bracing after surgery.

Received 05/17/2016

Review began 05/27/2016

Review ended 07/07/2016

Published 07/14/2016

\section{C) Copyright 2016}

Camara et al. This is an open access article distributed under the terms of the Creative Commons Attribution License CC-BY 3.0., which permits unrestricted use, distribution, and reproduction in any medium, provided the original author and source are credited.
Categories: Neurosurgery

Keywords: anterior cervical discectomy and fusion, external cervical orthoses, post-operative collar, cervical collar, cervical brace, neurosurgery, spine surgery

\section{Introduction And Background}

Cervical collars have been used in patients pre and postoperatively for anterior cervical discectomy and fusion (ACDF) surgeries with the goal of cervical immobilization. Since studies have shown that cervical collars decrease cervical spine mobility, collar use has often been assumed to prevent further spinal cord injury [1-3]. Additional potential benefits of cervical collars include the restriction of neck flexion, extension, lateral tilt (bending), and rotation [1]. Other studies have shown that cervical immobilization reduces pain and provides spinal stability [2-3]. The benefits of cervical orthoses are not just physical but also mental since external collars also provide patients with an increased sense of security [4].

Common characteristics are shared by the variety of cervical orthoses that exist $[1,5-10]$. To 
decrease cervical mobility, cervical orthoses are universally designed to provide an optimal fit against the jaw, occiput, and upper thorax [3]. While Halos are found to be more restrictive than soft collars [11], they do not completely eliminate mobility, despite the general consensus that rigid cervical orthoses are more limiting of cervical motion [2, 6, 8, 12-16]. Additionally, despite being less restrictive, soft collars may have an added benefit of increasing patient awareness due to enhanced proprioception $[10,17]$.

Some physicians recommend the use of postoperative cervical orthoses while others do not, and between surgeons who agree with postoperative collar usage the type of cervical orthoses and the duration of use are also topics of debate [18]. Because of this lack of professional consensus among spine surgeons regarding the use of external cervical orthoses (ECO) after ACDF, this review answers an important and relevant clinical question for spine surgeons performing ACDF procedures.

The purpose of this review is to evaluate the evidence for and against the use of ECO after ACDF. The question we ask is, “Does ECO after ACDF improve fusion rates?” By answering this question, we can improve patient outcomes, and if cervical orthoses are not recommended, reduce medical costs for patients.

\section{Review}

This review adheres to the reporting recommendations established by Stroup et al., and the Meta-analysis of Observational Studies in Epidemiology (MOOSE) Group [19] and was conducted by doctors of medicine to ensure proper assessment of clinical studies. A PubMed database search was conducted using the following keywords: "cervical collar fusion," "postoperative cervical immobilization," "postoperative cervical collar," "cervical immobilization fusion,” "postoperative cervical orthoses," “cervical orthoses fusion,” "neck collar fusion,” "postoperative neck collar," "postoperative surgical collar,” and "surgical collar fusion.” Our search yielded a total of 1,267 abstracts. These abstracts were individually reviewed, and full-text versions of relevant articles were obtained. Additionally, the related citations generated by PubMed and the bibliographies of relevant articles were reviewed. Studies investigating fusion rates after ACDF related to the presence or absence of external cervical collars were considered relevant. Studies that failed to meet this criterion were excluded. All studies obtained were in the English language, and no unpublished data were used. No search software or hand searching was used, and we did not establish contact with any authors of the reviewed papers. Due to the paucity of studies evaluating postoperative cervical spine stabilization after ACDF, we broadened our discussion to include a study evaluating complications after corpectomy/fusion (ACF). Finally, due to their direct relevance to the question under review, two questionnaires evaluating postoperative bracing practices among surgeons were included. All studies were critically appraised using the Grading of Recommendations Assessment, Development, and Evaluation (GRADE) approach developed by the GRADE working group and supported by The Cochrane Collaboration [20]. Because each study included for review chose to define fusion using slightly different criteria, rates of fusion success or failure reported in this review were calculated using the definitions established by each report.

In total, seven studies were included in this review. Using the GRADE approach, we ranked one of the studies as low quality of evidence and the remaining six articles as very low quality of evidence. A meta-analysis was not performed because the diversity of the studies included for review was too great. However, the total number of patients evaluated in five of the seven studies (two of the studies were questionnaires of surgeon preference) was 1,090 . Table 1 summarizes each article included in this review. 


\section{Cureus}

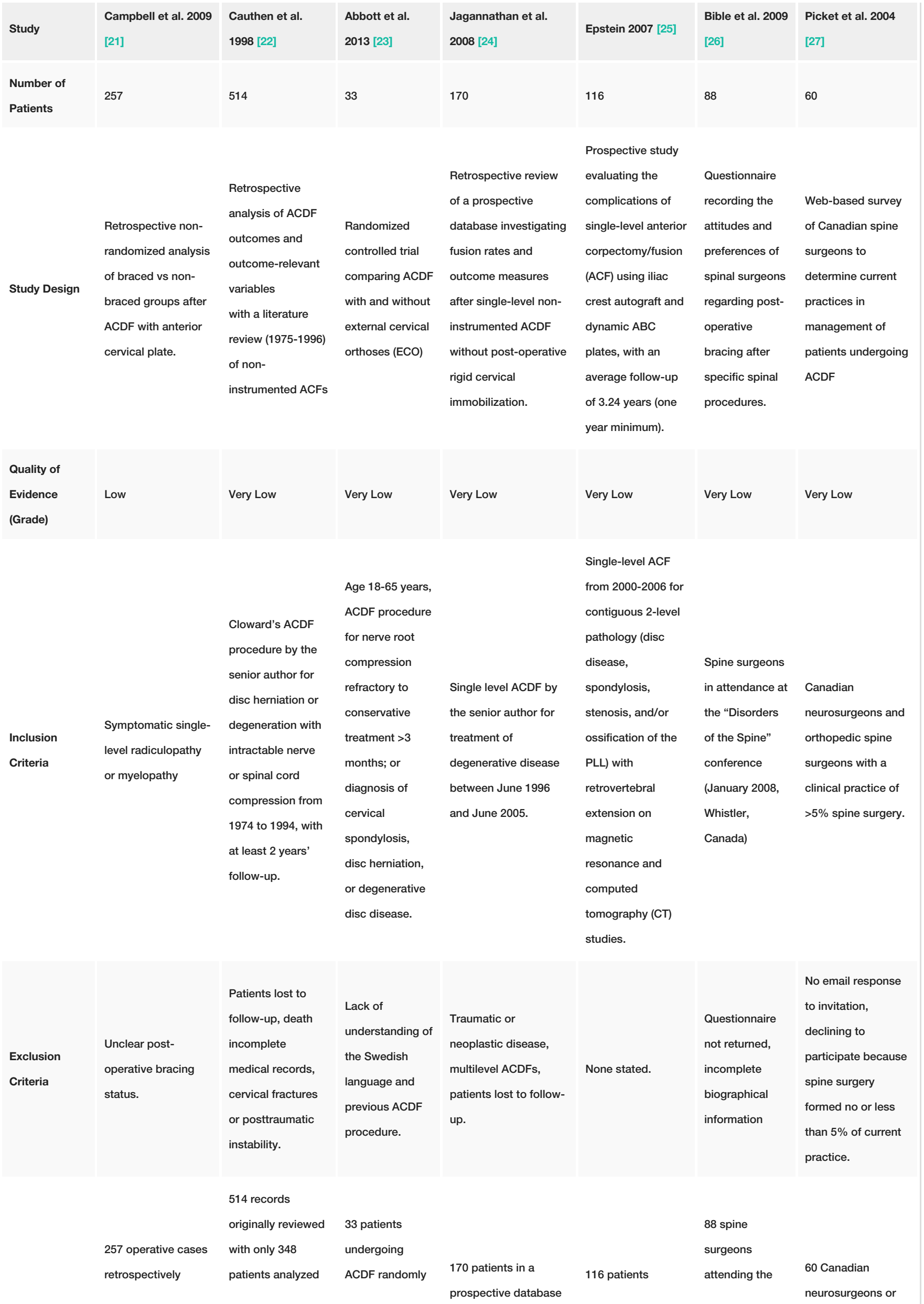




\section{Cureus}

\begin{tabular}{|c|c|c|c|c|}
\hline Population & $\begin{array}{l}\text { divided into two } \\
\text { groups } 149 \text { with } \\
\text { external orthoses, } \\
108 \text { without external } \\
\text { orthoses }\end{array}$ & $\begin{array}{l}\text { (based on } \\
\text { inclusion/exclusion } \\
\text { criteria) for a total } \\
\text { of } 21 \text { outcome and } \\
\text { outcome-relevant } \\
\text { variables, including } \\
\text { cervical collar use. }\end{array}$ & $\begin{array}{l}\text { assigned into } \\
\text { one of two } \\
\text { groups: } 17 \text { with } \\
\text { cervical collar } \\
\text { and } 16 \text { without } \\
\text { cervical collar }\end{array}$ & $\begin{array}{l}\text { retrospectively } \\
\text { evaluated for outcome } \\
\text { relevant variables after }\end{array}$ \\
\hline Demographics & $\begin{array}{l}\text { Groups were similar } \\
\text { for age, gender, and } \\
\text { Worker's } \\
\text { compensation; } \\
\text { dissimilar for } \\
\text { litigation, smoking, } \\
\text { and working. }\end{array}$ & $\begin{array}{l}47 \% \text { male, } 53 \% \\
\text { female with an } \\
\text { average age of } 40 \\
\text { years. } 202(58 \%) \\
\text { one-level fusions; } \\
129(37 \%) \text { two- } \\
\text { level; } 14(4 \%) \text { three } \\
\text { level; } 2(0.6 \%) \\
\text { four-level; and } 1 \\
\text { (0.3\%) five-level. } \\
\text { Graft source: } \\
\text { allograft ( } 70 \%) \text { and } \\
\text { autograft (30\%) }\end{array}$ & $\begin{array}{l}\text { The } \\
\text { randomization } \\
\text { process } \\
\text { produced even } \\
\text { group } \\
\text { distribution for } \\
\text { background } \\
\text { characteristics of } \\
\text { the patients and } \\
\text { baseline } \\
\text { variables. }\end{array}$ & 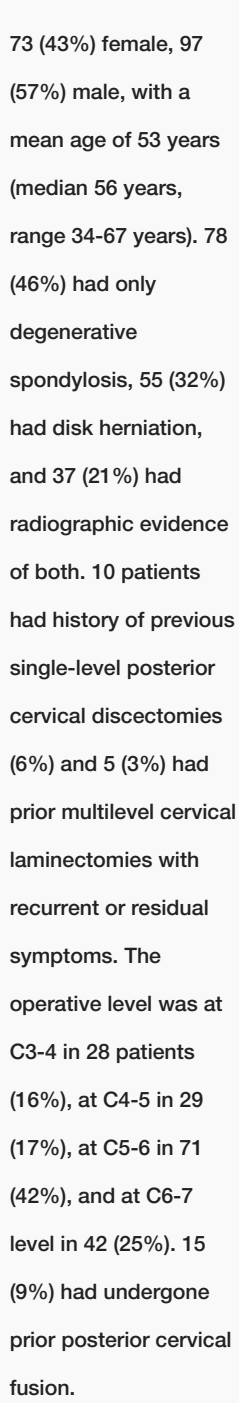 \\
\hline
\end{tabular}

undergoing single-
level ACF were
prospectively
followed.

"Disorders of
the Spine"
conference
(January 2008,
Whistler,
Canada)

Questionnaire

distributed to

118 surgeons

with 20 (25\%)

excluded. $55 \%$

of respondents

were orthopedic

surgeons and

$45 \%$ were

52 females and 64

males with an

average age of 45

(range 23-69).

Average

preoperative Nurick

Grade was 3.19

(moderate spastic

myelo-

radiculopathy). 43

patients weighed

over $200 \mathrm{lb}$, while

21 weighed over

240 lb.

neurosurgeons.

$66 \%$ affirmed

completion of a

spine

fellowship. $60 \%$

were in private

practice, and

$40 \%$ were in

academic

practice. $24 \%$

had practiced

for $<5$ years,

$32 \%$ for $5-10$

years, $27 \%$ for

10-15 years,

and $17 \%$ for

$>15$ years. $14 \%$

were currently

practicing in

countries other

than the USA. spinal orthopedic

surgeons invited by

email to complete a

questionnaire.

Email invitation was

sent to 159

surgeons $(59 \%$

neurosurgeons and

$41 \%$ orthopedic

surgeons). $72 \%$

were in academic

positions. $18 \%$ had

been in practice $<5$

years, $27 \%$ from 6 -

10 years, $33 \%$ from

11-20 years, and

$22 \%$ from $20-30$

years. Spine surgery

accounted for $54 \%$

of surgical practice

for the responding

neurosurgeons, and

$70 \%$ of practice for

the responding

orthopedic

surgeons.

Included the

documentation of

bony trabeculation

traversing the end

plate-graft interface

combined with the

lack of lucency on

2D-CT. Also

included the lack of

$n / a$

$\mathrm{n} / \mathrm{a}$

flexion-extension

radiographs, and

absence of radio-

lucencies.

operative

radiographs,

flexion/extension

graft interface on

translation, less

than $1 \mathrm{~mm}$ of

motion between

adjacent spinous 


\section{Cureus}

\begin{tabular}{|c|c|c|c|c|c|c|c|}
\hline & & $\begin{array}{l}\text { lucency was seen } \\
\text { without motion. }\end{array}$ & & & $\begin{array}{l}\text { processes, and less } \\
\text { than } 5 \text { degrees of } \\
\text { angulation. }\end{array}$ & & \\
\hline Results & $\begin{array}{l}\text { No significant } \\
\text { differences in fusion } \\
\text { success were seen } \\
\text { between groups as } \\
\text { assessed by } \\
\text { independent } \\
\text { radiologists. Higher } \\
\text { rates of non- } \\
\text { statistically } \\
\text { significant fusion } \\
\text { were reported in the } \\
\text { non-braced group } \\
\text { over all intervals. At } \\
6 \text { months, } 89.8 \% \\
\text { fusion rate was } \\
\text { reported in he } \\
\text { braced group and } \\
94.5 \% \text { in the non- } \\
\text { braced group } \\
\text { achieved fusion ( } P= \\
0.379) . \text { At } 24 \text { months, } \\
96.1 \% \text { fusion was } \\
\text { reported in the } \\
\text { braced group and } \\
100 \% \text { in the non- } \\
\text { braced group ( } P= \\
0.552) . \\
\text { (a) }\end{array}$ & $\begin{array}{l}\text { No significant } \\
\text { correlation was } \\
\text { found between } \\
\text { fusion and use of } \\
\text { postoperative } \\
\text { orthoses ( } 86 \% \\
\text { fusion rate with } \\
\text { cervical collar vs } \\
81 \% \text { fusion rate } \\
\text { without collar). }\end{array}$ & $\begin{array}{l}\text { Radiologists } \\
\text { noted no } \\
\text { qualitative } \\
\text { difference in } \\
\text { post-operative } \\
\text { fusion rates or } \\
\text { sagittal } \\
\text { alignment } \\
\text { between the } \\
\text { cervical collar } \\
\text { group and those } \\
\text { not prescribed a } \\
\text { post-operative } \\
\text { collar. } \\
\text { Radiographic } \\
\text { fusion rates were } \\
100 \% \text { in both } \\
\text { groups. }\end{array}$ & $\begin{array}{l} \\
\text { Postoperative } \\
\text { radiographs } \\
\text { demonstrated fusion } \\
\text { in } 160 \text { patients (94\%). } \\
\text { The high fusion rate } \\
\text { (94\%) and overall } \\
\text { favorable neurological } \\
\text { outcomes (96\%) } \\
\text { associated with non- } \\
\text { instrumented single- } \\
\text { level ACDF with no } \\
\text { postoperative collar } \\
\text { indicates that this is an } \\
\text { efficacious option in } \\
\text { treating cervical } \\
\text { spondylosis. }\end{array}$ & 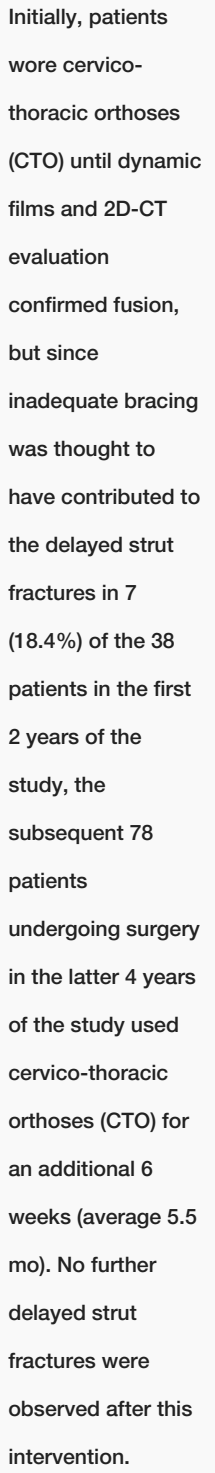 & $\begin{array}{l}\text { Only a slight } \\
\text { majority (56\%) } \\
\text { reported routine } \\
\text { use of cervical } \\
\text { or lumbar } \\
\text { orthoses post- } \\
\text { operatively. } \\
\text { A common } \\
\text { justification } \\
\text { reported was } \\
\text { that orthoses } \\
\text { "slow down" } \\
\text { patients and } \\
\text { remind them to } \\
\text { avoid certain } \\
\text { activities which } \\
\text { may } \\
\text { compromise } \\
\text { their clinical } \\
\text { outcomes. }\end{array}$ & $\begin{array}{l}\text { Surgeons } \\
\text { recommended ECO } \\
\text { for } 92 \% \text { of patients } \\
\text { without anterior } \\
\text { cervical plates and } \\
61 \% \text { of patients } \\
\text { with anterior } \\
\text { cervical plates for } \\
\text { reasons including } \\
\text { multilevel } \\
\text { pathology, concern } \\
\text { about bone strength } \\
\text { or screw placement, } \\
\text { patient discomfort, } \\
\text { and the 'routine.' }\end{array}$ \\
\hline $\begin{array}{l}\text { Study } \\
\text { Limitations }\end{array}$ & $\begin{array}{l}\text { We found no } \\
\text { limitations in the } \\
\text { ability of this } \\
\text { retrospective study } \\
\text { to compare fusion } \\
\text { rates between } \\
\text { braced and } \\
\text { unbraced groups. } \\
\text { Groups were } \\
\text { dissimilar for } \\
\text { smoking, but } \\
\text { because the non- } \\
\text { braced group had a } \\
\text { higher percentage of }\end{array}$ & $\begin{array}{l}166 \text { of } 514(32 \%) \\
\text { patient records } \\
\text { were unavailable } \\
\text { for follow-up. The } \\
\text { number of braced } \\
\text { and unbraced }\end{array}$ & $\begin{array}{l}\text { The study is } \\
\text { substantially } \\
\text { underpowered } \\
\text { to detect } \\
\text { differences in } \\
\text { fusion rates } \\
\text { between groups, } \\
\text { as there are } \\
\text { studies that } \\
\text { report a non- }\end{array}$ & $\begin{array}{l} \\
\text { No intra-study } \\
\text { comparison can be } \\
\text { made between ACDF } \\
\text { with external } \\
\text { immobilization and } \\
\text { ACDF without external } \\
\text { immobilization since }\end{array}$ & $\begin{array}{l}\text { The } \\
\text { results/conclusions } \\
\text { relevant to this } \\
\text { literature review } \\
\text { were made due to } \\
\text { a change in } \\
\text { protocol that } \\
\text { occurred at study } \\
\text { year } 2 \text { of } 6 . \\
\text { Additionally, } \\
\text { changes in surgical } \\
\text { technique made at } \\
\text { year } 2 \text { of } 6 \text { could } \\
\text { be a confounding }\end{array}$ & $\begin{array}{l}\text { The } \\
\text { questionnaire } \\
\text { required } \\
\text { participants to } \\
\text { assess their } \\
\text { own practice } \\
\text { patterns, } \\
\text { subjecting their } \\
\text { responses to } \\
\text { recall bias. It is } \\
\text { unclear whether } \\
\text { this data truly } \\
\text { reflects the } \\
\text { opinions and } \\
\text { preferences of }\end{array}$ & $\begin{array}{l}\text { All surveys suffered } \\
\text { from possible } \\
\text { reporting bias, and } \\
\text { a low response rate. } \\
\text { The list of surgeons } \\
\text { was compiled from } \\
\text { membership } \\
\text { information for the } \\
\text { North American } \\
\text { Spine Society, } \\
\text { Canadian Spine } \\
\text { Society, and the } \\
\text { Canadian Congress } \\
\text { of Neurological } \\
\text { Sciences. The } \\
\text { Canadian } \\
\text { Orthopedic }\end{array}$ \\
\hline
\end{tabular}




\section{Cureus}

\begin{tabular}{|c|c|c|c|c|c|c|c|}
\hline Conclusion & $\begin{array}{l}\text { The use of cervical } \\
\text { brace does not } \\
\text { improve the fusion } \\
\text { rate or the clinical } \\
\text { outcomes of } \\
\text { patients undergoing } \\
\text { single level-anterior } \\
\text { cervical fusion with } \\
\text { plating and is } \\
\text { probably } \\
\text { unnecessary. The } \\
\text { results of this study } \\
\text { should be confirmed } \\
\text { by randomized } \\
\text { clinical trials of } \\
\text { bracing versus no } \\
\text { bracing or other } \\
\text { similar studies of } \\
\text { patients enrolled in } \\
\text { current clinical trials. }\end{array}$ & $\begin{array}{l}\text { Fusion rate is } \\
\text { statistically } \\
\text { unrelated to } \\
\text { cervical collar use }\end{array}$ & $\begin{array}{l}\text { The results of } \\
\text { the study } \\
\text { suggest that } \\
\text { short-term } \\
\text { cervical collar } \\
\text { use post ACDF } \\
\text { and interbody } \\
\text { cage may help } \\
\text { certain patients } \\
\text { cope with initial } \\
\text { post-operative } \\
\text { pain and } \\
\text { disability. Larger } \\
\text { data collections } \\
\text { are required to } \\
\text { investigate } \\
\text { health-related } \\
\text { quality of life and } \\
\text { fusion rates in } \\
\text { patient with and } \\
\text { without rigid } \\
\text { collar use post } \\
\text { ACDF surgery. }\end{array}$ & $\begin{array}{l}\text { The results of the } \\
\text { study suggest that use } \\
\text { of post-operative } \\
\text { cervical collar is } \\
\text { unnecessary, as the } \\
\text { immediate and long- } \\
\text { term fusion rates did } \\
\text { not appear to be } \\
\text { affected by the lack of } \\
\text { immobilization. A } \\
\text { randomized controlled } \\
\text { trial will be essential in } \\
\text { determining the true } \\
\text { benefit of external or } \\
\text { internal fixation in } \\
\text { patients who undergo } \\
\text { single-level ACDF for } \\
\text { cervical spondylosis. }\end{array}$ & $\begin{array}{l}\text { variable. Also, this } \\
\text { study investigated } \\
\text { anterior ACF rather } \\
\text { than ACDF. } 43 \\
\text { patients weighed } \\
\text { over } 200 \mathrm{lbd} \text {, while } \\
21 \text { patients } \\
\text { weighed over } 240 \\
\text { Ibs, limiting } \\
\text { external validity. }\end{array}$ & $\begin{array}{l}\text { While the most } \\
\text { appropriate } \\
\text { indications for } \\
\text { postoperative } \\
\text { bracing are yet } \\
\text { to be } \\
\text { elucidated, it is } \\
\text { apparent that } \\
\text { well designed } \\
\text { clinical studies } \\
\text { evaluating the } \\
\text { relative } \\
\text { efficacies of } \\
\text { these diverse } \\
\text { regimens are } \\
\text { required so that } \\
\text { evidence-based } \\
\text { guidelines may } \\
\text { be available to } \\
\text { surgeons in the } \\
\text { future. }\end{array}$ & $\begin{array}{l}\text { Association was } \\
\text { excluded, based on } \\
\text { the assumption that } \\
\text { orthopedic spine } \\
\text { surgeons would be } \\
\text { captured by their } \\
\text { membership in } \\
\text { other organizations. } \\
\text { This may have } \\
\text { presented a } \\
\text { disproportionate } \\
\text { sampling of } \\
\text { neurosurgeons }\end{array}$ \\
\hline $\begin{array}{l}\text { Does ECO } \\
\text { improve } \\
\text { fusion rates } \\
\text { after ACDF? } \\
\text { (yes, no, } \\
\text { unknown) }\end{array}$ & No & No & Unknown & No & yes & Unknown & Unknown \\
\hline
\end{tabular}

\section{TABLE 1: Table summarizing the included articles}

In the first study, Campbell et al., [21] performed a retrospective analysis of 257 patients divided into braced (149 patients) and non-braced (108 patients) groups without randomization 
after decompression and arthrodesis using allograft and anterior cervical plate. Although the data for this study were collected during a randomized control trial, the actual design of this study is retrospective. The rate of fusion at six months was not statistically different between braced (89.8\%) and non-braced (94.5\%) groups ( $\mathrm{p}=0.379)$. At 24 months, the rate of fusion was once again not statistically different between the groups, with $96.1 \%$ fusion in the braced group and $100 \%$ fusion in the non-braced group $(\mathrm{p}=0.552)$. The results of this study indicate that external bracing after ACDF is not associated with improved fusion rates. We found minimal limitations in the ability of this study to retrospectively compare fusion rates between braced and non-braced groups that would suggest a high likelihood of bias. The population, intervention, control, and outcomes were all correctly designed to investigate the effect of external bracing on fusion rates. Using the ranking system developed by the GRADE working group, we rank the quality of this evidence as low (the highest possible for an observational study) due to the meeting of criteria for appropriate population, intervention, control, and outcomes [20].

In the second study, Cauthen et al., [22] performed a retrospective analysis of ACDF outcomes and outcome-relevant variables with a comprehensive literature review (1975-1996) of noninstrumented anterior cervical fusions. Three hundred forty-eight patients were analyzed for a variety of outcome-relevant variables, including cervical collar use. In this study, the fusion rates with and without a cervical collar were $86 \%$ and $81 \%$, respectively. Unfortunately, only fusion percentages were provided; the actual numbers of braced and non-braced patients were not indicated. The fusion rates with and without cervical collar use were not statistically different, and the authors of this study concluded that fusion rates are unrelated to the use of orthoses. It should be noted, however, that 166 of 514 (32\%) of the patient records were unavailable. This loss of patient data, although indicated as unavoidable by the study authors, severely limits the ability of the study to answer the question asked by this review. Using the criteria established by the GRADE working group, we rank the quality of this evidence as very low due to the loss of follow-up even though the study met criteria for appropriate population, intervention, controls, and outcomes [20].

In the third study, Abbott et al., [23] conducted a randomized controlled trial with 33 patients ACDF without ECO (16 patients) to ACDF with ECO (17 patients). Although the rate of fusion in both groups was $100 \%$, the effect of bracing on fusion rates cannot be determined due to low patient numbers. Even though the design of this study is a randomized controlled trial, the quality of evidence is lower than expected. Being a pilot study, the population size was too small to properly evaluate the effect of external bracing on fusion rates. Additionally, patients and investigators were not blinded to postoperative treatment allocation. Even though this study met criteria established by the GRADE working group for appropriate intervention, controls, and outcomes, we rank the quality of this evidence as very low due to the low population size and the lack of blinding [20].

In the fourth study, Jagannathan et al., [24] conducted a retrospective review of a prospective database investigating fusion rates and other neurological outcome measures after ACDF without the use of intraoperative plate placement or the use of postoperative rigid cervical immobilization in 170 patients. Fusion was recorded in 160 of the 170 (94\%) patients. Although $94 \%$ is an excellent fusion rate, the ability of this study to answer the question asked by this review is limited, since fusion rates were only investigated in patients without external bracing. The authors concluded that high fusion rates without external bracing render such orthoses as unnecessary. Due to meeting the criteria established by the GRADE working group for appropriate population, control, and outcomes but failing to meet criteria for appropriate intervention, lack of a braced group, we rank the quality of this evidence as very low [20].

In the fifth study, Epstein [25] performed a prospective study evaluating complications of single-level anterior corpectomy/fusion (ACF) using iliac crest autograft and dynamic ABC 
plates (Aesculap, Tuttlingen, Germany). Initially, all patients were braced using cervicothoracic orthoses (CTO) until dynamic films and 2D-CT evaluation confirmed fusion. However, in the first two years of the study, 7 of 38 (18.4\%) patients experienced delayed strut fractures. Thus, CTO use for the remaining 78 patients operated on during years 4-6 of the study was extended for an additional six weeks past the point of radiographic fusion confirmation. After this change in protocol, no further delayed strut fractures were observed. The authors posit that reduction of delayed strut fractures was associated with the extended CTO use. The ability of this study to answer the question asked by this review is limited because the intervention was single-level ACF rather than ACDF. Additionally, the recommendation to extend the time of external bracing was made based on a 'before and after' study design change that occurred at year 2 of 6. Furthermore, changes in surgical technique at year 2 make it impossible to ascertain whether the improved outcomes during years 2 through 6 were due to extended external bracing time. In addition, the weight of the patients included in this study may be a confounding variable with 43 of the 116 patients weighing over $200 \mathrm{lbs}$., and 21 of the patients weighing over 240 lbs. Even though this study met criteria established by the GRADE working group for appropriate outcomes, we rank the quality of this evidence as very low due to several limitations, including a non-ACDF procedure, a 'before and after' study design, and confounding variables, i.e., obesity and surgical procedure changes [20].

In the sixth study, Bible et al., [26] prepared a questionnaire to record the attitudes and preferences of spine surgeons regarding postoperative bracing after specific spinal procedures. One hundred eighteen questionnaires were distributed to spine surgeons attending the "Disorders of the Spine" conference hosted in Whistler, Canada in January 2008. Eightyeight questionnaires were included in the analysis. Results indicated that $56 \%$ percent of surgeons routinely use some type of external orthoses to complement the surgical treatment of the cervical and lumbar spine. Surgeons most commonly used external bracing to reduce motility while maintaining a safe level of activity. Because the lowest rank established by the GRADE working group for quality of evidence is very low and due to the natural tendency of all questionnaires to have a high bias and subjectivity, no recommendations for clinical practice can be made based upon the results of this study, and we rank the quality of this evidence as very low [20]. Although, this study is a poor source of information for clinical decision making, the fact that $56 \%$ of the surgeons routinely used external bracing while $44 \%$ did not make a clear argument for the necessity of this review.

In the seventh and final study included in this review, Pickett et al., [27] conducted a web-based survey of Canadian spine surgeons to determine current practices in the management of patients undergoing ACDF. Invitations to participate in the questionnaire were sent to 159 Canadian neurosurgeons or spinal orthopedic surgeons. Sixty surgeons were included in this analysis. According to the survey, surgeons recommended ECO for $92 \%$ of patients without anterior cervical plates and $61 \%$ of patients with anterior cervical plates. Surgeons indicated "multilevel pathology, concern regarding bone strength or screw placement, patient discomfort, and the 'routine'" as reasons for the use of external bracing. Using criteria established by the GRADE working group, we rank the quality of this evidence as very low [20]. Because no clinical recommendation can be made based upon the results of this study since questionnaires have no intervention or control and a tendency for bias. Although, once again, the inconsistent recommendation of external orthoses among spine surgeons argues for the necessity of this review.

In summary, one study provided low quality of evidence results supporting the conclusion that external bracing is not associated with improved fusion rates after ACDF [21]. The remaining six studies provided very low quality of evidence results. Two of these studies concluded that external bracing after cervical procedures is not associated with improved fusion rates [22, 24]. One of these studies concluded that external bracing after cervical procedures is associated with improved fusion rates [25]. The remaining three studies lacked sufficient evidence to draw 
an association between external bracing after ACDF and improved fusion rates [23, 26-27].

On a side note, patient compliance is one important topic we felt should have been addressed by these studies but was not. Unfortunately, none of these studies addressed rates of postoperative collar compliance [21-27]. We cannot exclude the possibility that low patient compliance is a confounding variable in the studies showing no difference between external orthoses and no external orthoses. If patients with low compliance for external orthoses had been excluded from the external orthoses groups in these studies, a statistical difference in fusion rates may have been observed. We conclude that although this lack of information is unfortunate, patient compliance is a reality of practicing clinical medicine, and clinical decision-making should take into account poor patient compliance. Therefore, although these studies do not address patient compliance, they still effectively answer the question under review through an intention-to-treat study design.

Additionally, length of collar usage differed among studies. To simplify the analysis of our proposed question, we treated collar wearing in a binary nature, worn or not worn, but in reality some patients were instructed to wear ECO until six weeks after radiographic fusion was observed (possibly 12 or more weeks) [25] while other patients were instructed to wear ECO for as little as one week [27]. Some surgeons even scaled the size of the recommended bracing time period with the number of spinal segments operated on [26]. Furthermore, wearing instructions differed among studies. Some patients were instructed to continuously wear ECO [25] while other patients were instructed to wear ECO only during the day or when moving around [23].

Finally, the use of cervical orthoses after ACDF is not without complications. Even though some of these sound extreme, reported complications of ECO include skin breakdown and damage [1, 3, 28], difficulty swallowing, coughing, difficulty breathing, and vomiting [29-30]. Other complications include marginal mandibular nerve palsy with long-term sensory compromise [31], potential increase in intracranial pressure [32], possible delayed extubation or difficulty weaning from the ventilator [29], potential exposure to the transmission of blood-born diseases [8], pressure points at sacrum, heels, and elbows secondary to general immobility [29, 33], decubitus ulcers [1, 34], and skin necrosis [35].

\section{Conclusions}

Based on the highest level of evidence and until a higher quality of evidence is available, we recommend against the routine use of ECO after ACDF due to a lack of improved fusion rates associated with external bracing after surgery. External bracing should be used only in patients with a specific need unrelated to fusion improvement in which the benefits of external bracing outweigh the risk of collar-related complications. Currently, the highest level of evidence supporting this conclusion is a retrospective study in which we found minimal design limitations [21]. The results of two additional studies also support this conclusion; however, we found limitations in their design [22, 24]. It should be noted that these studies did not report patient compliance. Thus, the effects of bracing on fusion rates in these studies may have been affected by the patients' compliance with bracing. In addition, the potential benefits of bracing may have been masked by other aspects of bracing, such as limited range of motion and reduced activity. Finally, some of these studies used differing techniques and hardware, which made comparison difficult. Further studies focusing on patient outcomes are necessary to further clarify ECO guidelines, including randomized studies of ACDF with or without ECO.

\section{Additional Information}

\section{Disclosures}

Conflicts of interest: In compliance with the ICMJE uniform disclosure form, all authors 
declare the following: Payment/services info: All authors have declared that no financial support was received from any organization for the submitted work. Financial relationships: All authors have declared that they have no financial relationships at present or within the previous three years with any organizations that might have an interest in the submitted work. Other relationships: All authors have declared that there are no other relationships or activities that could appear to have influenced the submitted work.

\section{References}

1. Webber-Jones JE, Thomas CA, Bordeaux RE Jr: The management and prevention of rigid cervical collar complications. Orthop Nurs. 2002, 21:19-25. 10.1097/00006416-20020700000004

2. Lunsford TR, Davidson M, Lunsford BR: The effectiveness of four contemporary cervical orthoses in restricting cervical motion. J Prosthetics \& Orthotics. 1994, 6:93-99.

3. Miller CP, Bible JE, Jegede KA, Whang PG, Grauer JN: The effect of rigid cervical collar height on full, active, and functional range of motion during fifteen activities of daily living. Spine. 2010, 35:E1546-E1552. 10.1097/BRS.0b013e3181cf6f73

4. Connolly PJ, Grob D: Controversy: bracing of patients after fusion for degenerative problems of the lumbar spine--yes or no?. Spine. 1998, 23:1426-1428. 10.1097/00007632-19980615000024

5. Stambolis V, Brady S, Klos D, Wesling M, Fatianov T, Hildner C: The effects of cervical bracing upon swallowing in young, normal, healthy volunteers. Dysphagia. 2003, 18:39-45. 10.1007/s00455-002-0083-2

6. Johnson RM, Owen JR, Hart DL, Callahan RA: Cervical orthoses: a guide to their selection and use. Clin Orthop Relat Res. 1981, 154:34-45.

7. Powers J, Daniels D, McGuire C, Hilbish C: The incidence of skin breakdown associated with use of cervical collars. J Trauma Nurs. 2006, 13:198-200. 10.1097/00043860-200610000-00016

8. Askins V, Eismont FJ: Efficacy of five cervical orthoses in restricting cervical motion. A comparison study. Spine. 1997, 22:1193-1198. 10.1097/00007632-199706010-00004

9. Tescher AN, Rindflesch AB, Youdas JW, et al.: Range-of-motion restriction and craniofacial tissue-interface pressure from four cervical collars. J Trauma. 2007, 63:1120-1126. 10.1097/TA.0b013e3180487d0f

10. Sandler AJ, Dvorak J, Humke T, Grob D, Daniels W: The effectiveness of various cervical orthoses. An in vivo comparison of the mechanical stability provided by several widely used models. Spine. 1996, 21:1624-1629. 10.1097/00007632-199607150-00002

11. Bell KM, Frazier EC, Shively CM, et al.: Assessing range of motion to evaluate the adverse effects of ill-fitting cervical orthoses. Spine J. 2009, 9:225-231. 10.1016/j.spinee.2008.03.010

12. Schneider AM, Hipp JA, Nguyen L, Reitman CA: Reduction in head and intervertebral motion provided by 7 contemporary cervical orthoses in 45 individuals. Spine. 2007, 32:E1-E6. 10.1097/01.brs.0000251019.24917.44

13. Colachis SC Jr, Strohm BR: Radiographic studies of cervical spine motion in normal subjects: flexion and hyperextension. Arch Phys Med Rehabil. 1965, 46:753-760.

14. James CY, Riemann BL, Munkasy BA, Joyner AB: Comparison of cervical spine motion during application among 4 rigid immobilization collars. J Athl Train. 2004, 39:138-145.

15. Kaufman WA, Lunsford TR, Lunsford BR, Lance LL: Comparison of three prefabricated cervical collars. Orthotics \& Prosthetics. 1986, 39:21-28.

16. Maiman D, Millington P, Novak S, Kerk J, Ellingsen J, Wenninger W: The effect of the thermoplastic Minerva body jacket on cervical spine motion. Neurosurgery. 1989, 25:363-367. 10.1097/00006123-198909000-00007

17. Johnson RM, Hart DL, Simmons EF, Ramsby GR, Southwick WO: Cervical orthosis. a study comparing their effectiveness in restricting cervical motion in normal subjects. J Bone Joint Surg Am. 1977, 59:332-339.

18. Naylor JR, Mulley GP: Surgical collars: a survey of their prescription and use . Br J Rheumatol. 1991, 30:282-284. 10.1093/rheumatology/30.4.282

19. Stroup DF, Berlin JA, Morton SC, et al.: Meta-analysis of observational studies in epidemiology: a proposal for reporting. JAMA. 2000, 283:2008-2012.

10.1001/jama.283.15.2008 
20. Cochrane Handbook of Systematic Reviews Of Interventions . Cochrane Book Series. Higgins JPT, Green S (ed): John Wiley \& Sons, Ltd., Chichester, UK; 2011. 12.2.1.

10.1002/9780470712184

21. Campbell MJ, Carreon LY, Traynelis V, Anderson PA: Use of cervical collar after single-level anterior cervical fusion with plate: is it necessary?. Spine. 2009, 34:43-48.

10.1097/BRS.0b013e318191895d

22. Cauthen JC, Kinard RE, Vogler JB, et al.: Outcome analysis of noninstrumented anterior cervical discectomy and interbody fusion in 348 patients. Spine. 1998, 23:188-192.

10.1097/00007632-199801150-00008

23. Abbott A, Halvorsen M, Dedering A: Is there a need for cervical collar usage post anterior cervical decompression and fusion using interbody cages? a randomized controlled pilot trial. Physiother Theory Pract. 2013, 29:290-300. 10.3109/09593985.2012.731627

24. Jagannathan J, Shaffrey CI, Oskouian RJ, et al.: Radiographic and clinical outcomes following single-level anterior cervical discectomy and allograft fusion without plate placement or cervical collar. J Neurosurg Spine. 2008, 8:420-428. 10.3171/SPI/2008/8/5/420

25. Epstein NE: Complication avoidance in 116 dynamic-plated single-level anterior corpectomy and fusion. J Spinal Disord Tech. 2007, 20:347-351. 10.1097/01.bsd.0000248257.10284.3b

26. Bible JE, Biswas D, Whang PG, Simpson AK, Rechtine GR, Grauer JN: Postoperative bracing after spine surgery for degenerative conditions: a questionnaire study. Spine J. 2009, 9:309316. 10.1016/j.spinee.2008.06.453

27. Pickett GE, Van Soelen J, Duggal N: Controversies in cervical discectomy and fusion: practice patterns among Canadian surgeons. Can J Neurol Sci. 2004, 31:478-483.

\subsection{7/S0317167100003668}

28. Elliott RE, Tanweer O, Boah A, et al.: Is external cervical orthotic bracing necessary after posterior atlantoaxial fusion with modern instrumentation: meta-analysis and review of literature. World Neurosurg. 2013, 79:369-374. 10.1016/j.wneu.2012.03.022

29. Dibsie LG: Clearing cervical spine injuries: a discussion of the process and the problems . Crit Care Nurs Q. 1998, 21:36-41.10.1097/00002727-199808000-00005

30. Krock N: Immobilizing the cervical spine using a collar. Complications and nursing management. Axone. 1997, 18:52-55.

31. Rodgers JA, Rodgers WB: Marginal mandibular nerve palsy due to compression by a cervical hard collar. J Orthop Trauma. 1995, 9:177-179.

32. Kolb JC, Summers RL, Galli RL: Cervical collar-induced changes in intracranial pressure . Am J Emerg Med. 1999, 17:135-137. 10.1016/S0735-6757(99)90044-X

33. Clancy MJ: Clearing the cervical spine of adult victims of trauma . J Accid Emerg Med. 1999, 16:208-214. 10.1136/emj.16.3.208

34. Ackland HM, Cooper DJ, Malham GM, Kossmann T: Factors predicting collar-related decubitus ulceration in major trauma patients. Spine (Phila Pa 1976). 2007, 32:423-428. 10.1097/01.brs.0000255096.52871.4e

35. Hewitt S: Skin necrosis caused by a semi-rigid cervical collar in a ventilated patient with multiple injuries. Injury. 1994, 25:323-324. 10.1016/0020-1383(94)90245-3 